\title{
Novel Insight into the in vivo Function of Mast Cell Chymase: Lessons from Knockouts and Inhibitors
}

\author{
Gunnar Pejler \\ Department of Medical Biochemistry and Microbiology, Uppsala University, Uppsala, Sweden; Department of \\ Anatomy, Physiology and Biochemistry, Swedish University of Agricultural Sciences, Uppsala, Sweden
}

\section{Keywords}

Chymase $\cdot$ Mast cells $\cdot$ Knockout $\cdot$ Inhibitors

\begin{abstract}
Mast cells are now recognized as key players in diverse pathologies, but the mechanisms by which they contribute in such settings are only partially understood. Mast cells are packed with secretory granules, and when they undergo degranulation in response to activation the contents of the granules are expelled to the extracellular milieu. Chymases, neutral serine proteases, are the major constituents of the mast cell granules and are hence released in large amounts upon mast cell activation. Following their release, chymases can cleave one or several of a myriad of potential substrates, and the cleavage of many of these could potentially have a profound impact on the respective pathology. Indeed, chymases have recently been implicated in several pathological contexts, in particular through studies using chymase inhibitors and by the use of chymase-deficient animals. In many cases, chymase has been shown to account for mast cell-dependent detrimental effects in the respective conditions and is therefore emerging as a promising drug target. On the
\end{abstract}

\begin{tabular}{ll}
\hline karger@karger.com & (C) 2020 The Author(s) \\
www.karger.com/jin & Published by S. Karger AG, Basel Karger \\
& This article is licensed under the Creative Commons Attribution- \\
Karger & NonCommercial-NoDerivatives 4.0 International License (CC BY- \\
NC-ND) (http://www.karger.com/Services/OpenAccessLicense). \\
Usage and distribution for commercial purposes as well as any dis- \\
tribution of modified material requires written permission.
\end{tabular}

other hand, chymase has been shown to have protective roles in other pathological settings. More unexpectedly, chymase has also been shown to control certain homeostatic processes. Here, these findings are reviewed.

(c) 2020 The Author(s)

Published by S. Karger AG, Basel

\section{Introduction}

Mast cells are currently emerging as key actors in many types of immune responses, having either beneficial or detrimental activities depending on the particular setting. Undoubtedly, mast cells are mostly well known for their harmful effects in allergic reactions, but detrimental activities of mast cells have also been reported in other settings, including arthritis, dermatitis, obesity, atherosclerosis, abdominal aortic aneurysms and cancer [reviewed in 1-4]. However, mast cells are also well recognized for their protective functions in the immunity towards a variety of pathogens, including bacteria, viruses and parasites [5-7].

Based on this development, it is important to investigate the mechanisms behind the contribution of mast

Prof. Gunnar Pejler

Department of Medical Biochemistry and Microbiology, Uppsala University BMC, Box 582

SE-75123 Uppsala (Sweden)

Gunnar.Pejler@imbim.uu.se 
Table 1. Mast cell chymases in humans and mice

\begin{tabular}{|c|c|c|c|c|c|c|}
\hline Chymase & $\begin{array}{l}\text { Chymase } \\
\text { family }\end{array}$ & Enzymatic activity & MC subclass & $\begin{array}{l}\text { Interaction } \\
\text { with serglycin }\end{array}$ & Knockout & $\begin{array}{l}\text { Chromosomal } \\
\text { location }\end{array}$ \\
\hline \multicolumn{6}{|l|}{ Human } & $14 \mathrm{q} 12$ \\
\hline \multicolumn{7}{|l|}{ Mouse } \\
\hline Mcpt1 (mMCP1) & $\beta$ & chymotrypsin-like & MMC & - & Wastling et al. [21] & $\begin{array}{l}14 \mathrm{C} 3 ; 1428.19 \\
\mathrm{cM}\end{array}$ \\
\hline Mcpt2 (mMCP2) & $\beta$ & non-active & MMC & $(+)$ & not available & $\begin{array}{l}14 \mathrm{C} 3 ; 1428.19 \\
\mathrm{cM}\end{array}$ \\
\hline Mcpt4 (mMCP4) & $\beta$ & chymotrypsin-like & CTMC & + & Tchougounova et al. [23] & $\begin{array}{l}14 \text { C3; } 1428.19 \\
\text { cM }\end{array}$ \\
\hline Mcpt5 (mMCP5) & $a$ & elastase-like & CTMC & + & Abonia et al. [22] & $\begin{array}{l}14 \mathrm{C} 3 ; 1428.19 \\
\mathrm{cM}\end{array}$ \\
\hline Mcpt9 (mMCP9) & $\beta$ & chymotrypsin-like & $\begin{array}{l}\text { uterine-specific } \\
\text { (CTMC) }\end{array}$ & $+($ predicted $)$ & not available & $\begin{array}{l}14 \mathrm{C} 3 ; 1428.19 \\
\mathrm{cM}\end{array}$ \\
\hline
\end{tabular}

MC, mast cell; CMA1, $\mathrm{MC}_{\mathrm{TC}}$, subtype also expressing tryptase and carboxypeptidase A3; MMC, mucosal mast cell; CTMC, connective tissue mast cell. ${ }^{\text {a }}$ Humans with altered chymase expression have not been identified.

cells to these diverse pathological settings, and, indeed, this is a major current focus for many laboratories worldwide. When mast cells are activated, which can be accomplished by IgE-mediated and a range of other mechanisms [4], they may respond by degranulation. This causes a massive release of the preformed mediators that are stored within the mast cell secretory granules [8]. Clearly, one mode by which mast cells could influence a given inflammatory condition is by effects attributed to these released compounds, a notion that is gaining support from recent research [8].

The preformed mast cell mediators include biogenic amines (histamine, serotonin), serglycin proteoglycan, certain preformed cytokines (e.g., tumor necrosis factor, $\mathrm{TNF}$ ) and a number of mast cell-specific proteases, the latter encompassing chymases, tryptases and carboxypeptidase A3 [8-10]. However, activation of mast cells does not necessarily lead to degranulation, as evidenced by the ability of mast cells to release numerous inflammatory mediators under circumstances where degranulation is not evident [4]. It should also be emphasized that several of the compounds released by activated mast cells are synthesized de novo, rather than being released from preformed pools [4].

Chymases belong to the large family of serine proteases, and their expression is essentially unique to mast cells [11-13]. Mast cells can express high levels of chymase-encoding mRNA, previous findings having re- vealed that up to $2.5 \%$ of the total mRNA pool in mast cells can code for chymases $[13,14]$. Notably, chymase expression in mast cells is constitutive and in most cases not affected to any major extent by mast cell activation [10]. The high expression of chymase mRNA is also reflected at the protein level, where it has been calculated that chymases can account for up to $25 \%$ of the total cellular protein of mast cells $[15,16]$.

For many years, the knowledge of the in vivo function of chymase was quite rudimentary, mainly based on data from in vitro experiments. However, the generation of chymase-deficient animals and the development of selective chymase inhibitors have opened up possibilities for investigations of the in vivo function of mast cell chymase. By using these tools, important insight into the biological function of chymase has been obtained and has revealed an important role for chymase in modulating a diverse array of pathological but also homeostatic conditions. Here, these findings are reviewed.

\section{Chymases and Chymase Knockout Strains}

In humans, only one mast cell chymase gene is expressed (CMA1; classified as an $\alpha$-chymase), located on chromosome 14 (Table 1). In contrast, the corresponding chymase locus on chromosome 14 in mice has un- 
dergone extensive expansion, and encompasses 5 chymase genes: Mcpt1 (previously denoted MMCP1; classified as a $\beta$-chymase), Mcpt2 (mMCP2; $\beta$-chymase), Mcpt4 (mMCP4; $\beta$-chymase), Mcpt5/Cma1 (mMCP5; $\alpha$-chymase) and Mcpt9 (mMCP9; $\beta$-chymase) [10]. The chymase expression profile differs among mast cell subtypes. In humans, chymase is expressed by the $\mathrm{MC}_{\mathrm{TC}}$ subtype (also expressing tryptase and carboxypeptidase A3), which are predominant in skin but also found in many other locations. In the mouse, mast cells are generally divided into connective tissue- (CTMC) and mucosal (MMC)-type mast cells, of which CTMCs are found in skin and various other locations such as intestinal submucosa, tongue and trachea, whereas MMCs are predominant in the intestinal mucosa. CTMCs and MMCs differ with regard to chymase expression, with CTMCs expressing Mcpt4 and Mcpt5, whereas MMCs express Mcpt1 and Mcpt2. However, mixed phenotypes have been identified, e.g. in the lung, in which mast cells can express both CTMC and MMC chymases [17].

Mcpt4 and Mcpt5 are both strongly dependent on electrostatic interactions with sulfated (thereby negatively charged) serglycin proteoglycans for storage in mast cell granules, as shown by a major reduction in the respective proteins (but not mRNA) in serglycin ${ }^{-/-}$mast cells [18]. Also, the lack of NDST2, an enzyme that is essential for the sulfation of serglycin proteoglycans, causes a strong reduction in the storage of Mcpt4 and Mcpt5 [19]. In contrast, Mcpt1 storage is independent of serglycin, whereas Mcpt2 storage is partly serglycin-dependent [20].

Based on amino acid sequence similarities, Mcpt5 may be regarded as the homologue to human chymase (both are classified as $\alpha$-chymases). However, Mcpt5 and human chymase have fundamentally divergent substrate cleavage profiles (see "Enzymatic properties of chymases"). For this reason, Mcpt5 is most likely not the functional counterpart to human chymase. Of the remaining murine chymases, Mcpt 4 has a similar substrate cleavage profile to human chymase (see "Enzymatic properties of chymases"), has a similar tissue distribution and also has similar proteoglycan-binding properties to human chymase. In contrast, Mcpt1, Mcpt2 and Mcpt9 all have different expression patterns as compared with human chymase. Hence, out of the murine chymases, Mcpt 4 may be regarded as a close functional homologue to human chymase, and studies on Mcpt4-deficient animals may thus provide particularly important clues to the function of human chymase.

Mast Cell Chymase
The first reported chymase knockout came from Miller's group, who reported the targeted deletion of Mcpt1 [21]. Also Mcpt5 [22] and Mcpt4 [23] knockouts have been generated but, to date, knockouts for Mcpt2 and Mcpt9 have not been reported.

\section{Enzymatic Properties of Chymases}

Chymases are monomeric serine proteases, i.e., their active sites contain a Ser-His-Asp catalytic triad, of which the serine has a direct role in cleaving the target peptide bond by forming a covalent intermediate. Chymases are endopeptidases, i.e. have the ability to cleave proteins/ peptides within the interior of the peptide chains. In terms of cleavage specificity, chymases are chymotrypsinlike and thereby show strong preference for peptide bonds with an aromatic amino acid residue (Phe, Tyr, Trp) on the N-terminal side of the scissile bond (the $\mathrm{P} 1$ position) [24]. With regard to the extended substrate cleavage specificities, different chymases have variable preferences. Human chymase (CMA1) has a strong preference for peptide bonds where an acidic residue (Asp, Glu) is located two amino acids C-terminal of the cleavage bond (P2' position) and has also preference for aliphatic amino acid residues at positions $\mathrm{P} 2-\mathrm{P} 4$ [25]. These preferences are largely shared by Mcpt4 [26], supporting the notion that Mcpt4 represents the functional homologue to human chymase. Mcpt1, in contrast, lacks the preference for an acidic $\mathrm{P} 2$ ' residue, prefers $\mathrm{Phe}$ at the $\mathrm{P} 1$ position, shows preference for Ser at P1', prefers large hydrophobic residues at $\mathrm{P} 2$ and aliphatic residues at P3-P4 [27]. Mcpt2 is considered to be enzymatically inactive $[28,29]$. Mcpt5, although being structurally more similar to CMA1 than Mcpt4 in terms of amino acid sequence homology, has evolved elastase-like (prefers aliphatic amino acid residues at the P1 position) rather than chymotrypsin-like specificity [30].

With regard to macromolecular substrates, chymase has been shown to cleave large numbers of proteins/peptides, including fibronectin [23,31,32], procollagenase [33], pro-MMP9 [34-36], pro-MMP2 [35, 37], IL-6 [38, 39], IL-13 [38], IL-15 [39], IL-33 [39, 40], pro-IL1 $\beta$ [41], pro-IL-18 [39, 42], TNF [43], CCL6/9/15/23 [44], angiotensin I [45], thrombin [23, 46, 47], latent transforming growth factor $\beta$ (TGF- $\beta$ ) [48-50], vasoactive intestinal peptide [51], substance P [51], HMGB1 [52], tight junction proteins $[37,53]$, big-endothelin-1 [54], chemerin [55] and CTAP-III [56] (Fig. 1; see also [57]). However, many of these substrates have been identified through ex-

J Innate Immun 2020;12:357-372

DOI: $10.1159 / 000506985$ 


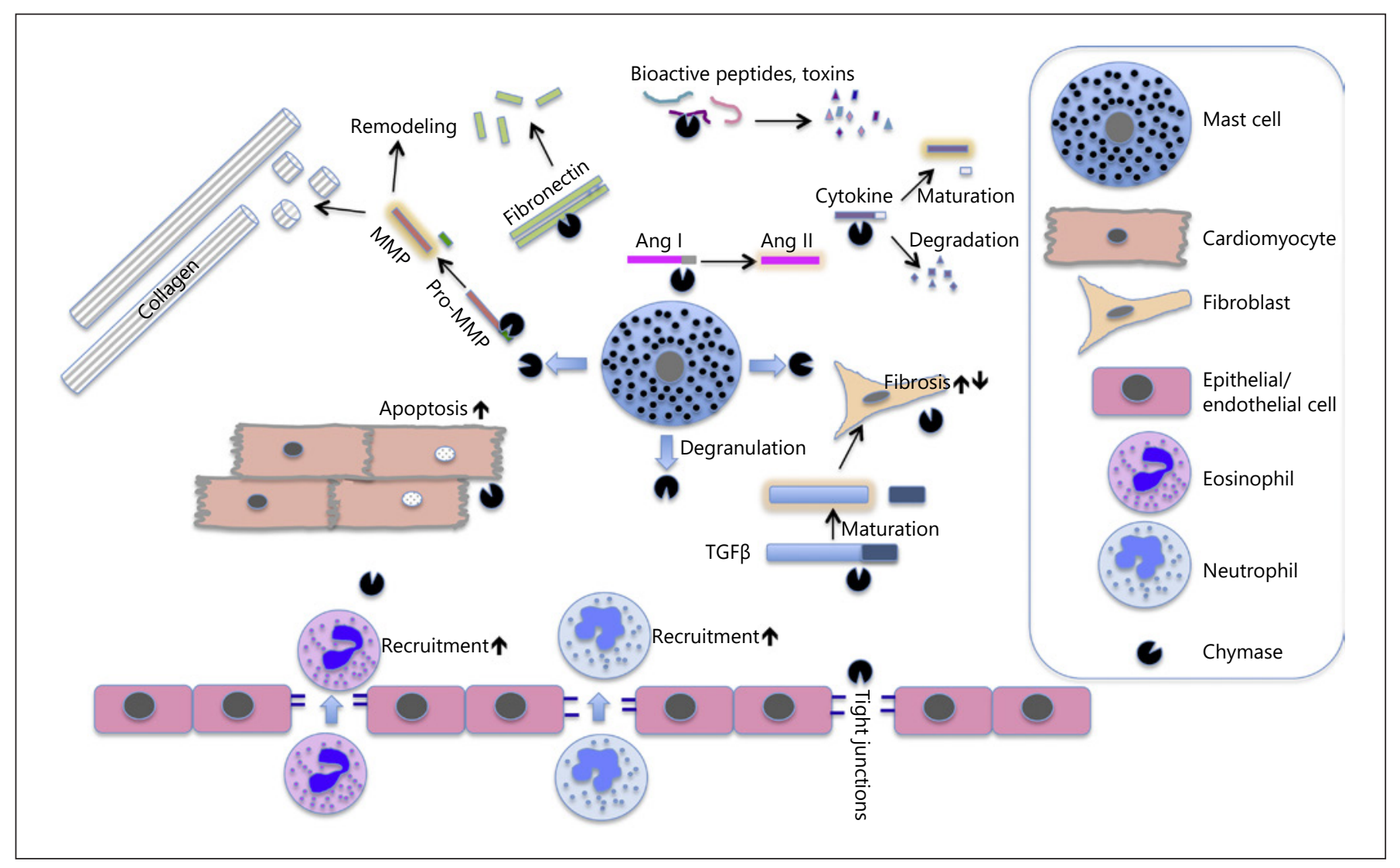

Fig. 1. Examples of mast cell chymase function. MMP, matrix metalloproteinase; TGF- $\beta$, transforming growth factor $\beta$.

periments in purified systems, and it is not certain whether all of them represent physiological targets for chymase in vivo.

\section{Chymase Inhibitors}

Several synthetic, selective chymase inhibitors have been developed over the last few decades (Table 2). These have been assessed for effects in various disease models (see below), and, in many cases, promising beneficial effects of such inhibitors have been seen, hence supporting a role for chymase in the respective condition. However, it is important to note that chymase is highly similar to neutrophil cathepsin $\mathrm{G}$ in terms of cleavage specificity, and many of the developed chymase inhibitors also target cathepsin G, at least to some extent (Table 2). For several of the used chymase inhibitors, their selectivity over cathepsin $\mathrm{G}$ has not been reported (Table 2). Hence, it is not clear under all circumstances whether effects of chymase inhibitors are indeed due to inhibition of chymase, as op- posed to off-target inhibition of cathepsin G. Moreover, chymase inhibitors are usually developed to target human chymase rather than the corresponding endogenous chymase type expressed by the respective experimental animals. Hence, it is in many cases not clear whether the intended target chymase is in fact efficiently inhibited by the applied inhibitor. These considerations should be taken into account, and some caution should accordingly be taken when interpreting data derived from usage of chymase inhibitors in animal models for disease.

\section{Biological Functions of Chymases: General Considerations}

As discussed below, based on studies of chymase knockout animals and on pharmacological chymase inhibition, a role for chymase in a multitude of pathological (and nonpathological) contexts has been identified (Table 3; Fig. 1). At first sight, the range of proposed functions for chymase may seem bewildering. Moreover, it may seem contradic- 
Table 2. Chymase inhibitors

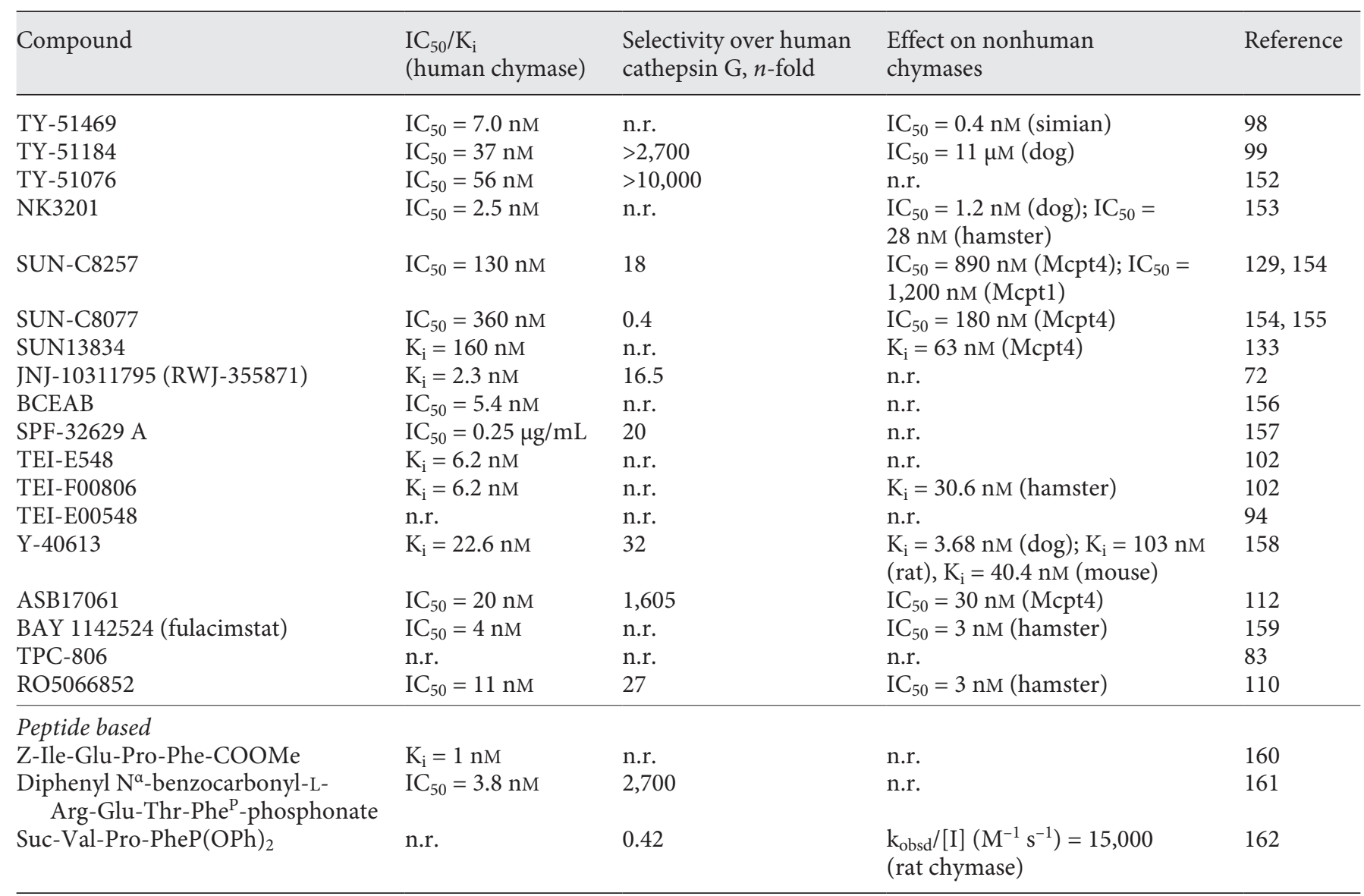

n.r., not reported in the scientific literature; $\mathrm{k}_{\mathrm{obsd}}$, pseudo-first order rate constant.

tory that chymase, in some contexts, can in fact have an opposing impact depending on the exact setting and on the specific tools used. However, it is important to note that chymase-expressing mast cells are widely distributed in the body and thereby are present, either as resident or recruited cells, in the context of multiple pathologies. Moreover, it is known that mast cells can undergo degranulation (and thereby release chymase) in response to a wide panel of stimulants [4], and it is also important to emphasize that chymase is a major component of mast cell granules. Consequently, large amounts of released chymase will be present in a very wide panel of pathologies. It is also important to note that chymase can cleave a large range of substrates (see "Enzymatic properties of chymases"), and the cleavage of the respective substrates can have highly variable consequences, ranging from protective functions by degrading harmful/proinflammatory substances to a detrimental impact by activating molecules that contribute to the pathology
(Fig. 1). The exact impact of chymase will thus be dependent on the availability of potential chymase substrates under the respective condition. Clearly, the levels and repertoire of chymase substrates may vary extensively between different pathological settings, and also under different phases of the respective condition. The wide array of functions for chymase may thus be a reflection of its presence under the respective settings, and the variable impact of chymase may reflect the variable repertoire of available chymase substrates in different conditions and in different phases of these.

\section{Chymase in Host Defense}

Mast cells show a preferential localization to sites in close contact with the external environment, such as skin and mucosal surfaces of the gut and lung. Based on this and on that mast cells express numerous pattern recognition recep- 
Table 3. Detrimental and protective functions of chymase

\begin{tabular}{|c|c|c|c|c|c|}
\hline Condition & Role of chymase & $\begin{array}{l}\text { Supported } \\
\text { by studies in } \\
\text { knockout mice }\end{array}$ & $\begin{array}{l}\text { Supported } \\
\text { by chymase } \\
\text { inhibition }\end{array}$ & Proposed impact of chymase & Reference \\
\hline
\end{tabular}

\begin{tabular}{|c|c|c|c|c|c|}
\hline $\begin{array}{l}\text { Abdominal aortic } \\
\text { aneurysms }\end{array}$ & detrimental & yes & yes & $\begin{array}{l}\text { MMP9 generation; monocyte } \\
\text { recruitment; regulation of } \\
\text { cysteine cathepsins; elastin } \\
\text { degradation; angiogenesis; } \\
\text { vascular cell apoptosis }\end{array}$ & 111,112 \\
\hline
\end{tabular}

\begin{tabular}{|c|c|c|c|c|c|}
\hline Adhesions & detrimental & no & yes & TGF- $\beta$ generation & $145-149$ \\
\hline Atherosclerosis & detrimental & yes & yes & $\begin{array}{l}\text { promotion of necrosis; adverse } \\
\text { effect on plaque stability }\end{array}$ & 109,110 \\
\hline Atopic dermatitis & detrimental & no & yes & itch induction; proinflammatory & $129,133,144$ \\
\hline $\begin{array}{l}\text { Bleomycin-induced lung } \\
\text { inflammation/fibrosis }\end{array}$ & detrimental & yes & yes & profibrotic; proinflammatory & 74,75 \\
\hline Bullous pemphigoid & detrimental & yes & no & $\begin{array}{l}\text { MMP9 generation; } \\
\text { hemidesmosome degradation }\end{array}$ & 36 \\
\hline Diabetes & detrimental & no & yes & $\begin{array}{l}\text { albuminuria; pancreatic island } \\
\text { damage; oxidative stress; Ang II } \\
\text { generation }\end{array}$ & $121-123$ \\
\hline $\begin{array}{l}\text { Experimental autoimmune } \\
\text { encephalomyelitis }\end{array}$ & detrimental & yes & no & proinflammatory & 80 \\
\hline $\begin{array}{l}\text { Lung inflammation } \\
\text { (LPS, silicosis) }\end{array}$ & detrimental & no & yes & $\begin{array}{l}\text { neutrophil influx; cytokine } \\
\text { induction }\end{array}$ & 72,73 \\
\hline $\begin{array}{l}\text { Nephritis (partial } \\
\text { ureteral obstruction) }\end{array}$ & detrimental & yes & no & $\begin{array}{l}\text { fibrosis; CCL2 production; } \\
\alpha \text {-smooth muscle actin expression }\end{array}$ & 125 \\
\hline $\begin{array}{l}\text { Nephritis (unilateral } \\
\text { ureteral obstruction) }\end{array}$ & protective & yes & no & $\begin{array}{l}\text { suppression of fibrosis/ } \alpha \text {-smooth } \\
\text { muscle actin/collagen deposition/ } \\
\text { CCL2/TGF- } \beta\end{array}$ & 32 \\
\hline
\end{tabular}


Table 3 (continued)

\begin{tabular}{|c|c|c|c|c|c|}
\hline Condition & Role of chymase & $\begin{array}{l}\text { Supported } \\
\text { by studies in } \\
\text { knockout mice }\end{array}$ & $\begin{array}{l}\text { Supported } \\
\text { by chymase } \\
\text { inhibition }\end{array}$ & Proposed impact of chymase & Reference \\
\hline $\begin{array}{l}\text { Posttraumatic brain } \\
\text { inflammation }\end{array}$ & protective & yes & yes & $\begin{array}{l}\text { regulation of astrogliosis and } \\
\mathrm{T} \text {-cell infiltration/microglia } \\
\text { infiltration }\end{array}$ & 141 \\
\hline $\begin{array}{l}\text { Posttraumatic spinal cord } \\
\text { damage }\end{array}$ & protective & yes & no & $\begin{array}{l}\text { degradation of proinflammatory } \\
\text { cytokines/chemokines; limiting of } \\
\text { scar formation: modulation of } \\
\text { scar protein expression }\end{array}$ & 139,140 \\
\hline Steatohepatitis & detrimental & no & yes & $\begin{array}{l}\text { contribution to fibrosis; collagen } \\
\text { induction; Ang II generation; } \\
\text { a-smooth muscle actin induction; } \\
\text { MMP9 generation }\end{array}$ & $114-118$ \\
\hline $\begin{array}{l}\text { Thrombin-induced skin } \\
\text { inflammation }\end{array}$ & protective & & & degradation of thrombin & 47 \\
\hline $\begin{array}{l}\text { Trichinella spiralis } \\
\text { infection }\end{array}$ & protective & yes & no & $\begin{array}{l}\text { promotes parasite expulsion; } \\
\text { inhibits muscle larva deposition }\end{array}$ & 58 \\
\hline
\end{tabular}

MMP, matrix metalloproteinase; TGF- $\beta$, transforming growth factor $\beta$; Ang, angiotensin; $\mathrm{T}_{\text {reg, }}$, regulatory T cells; LPS, lipopolysaccharide; CCL2, CC chemokine ligand 2; TNF, tumor necrosis factor; MCP-1, monocyte chemotactic protein 1.

tors capable of sensing a plethora of pathogen-expressed factors [5], it is generally thought that mast cells are important sentinel cells acting in the early phases of innate immune responses against pathogens [5-7]. Regarding the mechanism(s) by which mast cells confer protection against infectious agents, there is evidence that chymase can contribute to such protective functions. In an early study, Knight et al. [58] showed that mice lacking Mcpt1 display a delayed expulsion of the nematode Trichinella spiralis and increased deposition of larvae in tissues. In contrast, the expulsion of Nippostrongylus brasiliensis was not affected by the absence of Mcpt1, indicating that mast cell chymases preferentially act against selected parasite worms [58]. Chymase has also been shown to have a role in protection against various types of bacterial insults. In a model where sepsis is induced by cecal ligation and puncture, it was demonstrated that the absence of Mcpt4 resulted in markedly more severe pathology than that seen in wild-type mice [43], and data were presented to suggest that the protective effect of Mcpt4 was due to its ability to suppress the levels of TNF [43]. In subsequent studies it was shown that Mcpt4 can additionally reduce the severity of group B streptococcus infections by degrading fibronectin in the extracellular matrix of the host, thereby reducing bacterial adherence [59]. On a different angle, it has been demonstrated that Mcpt2 can have a protective role in the cecal ligation and puncture model, and that IL-15 can constrain antibacterial defense capabilities of mast cells by downregulating Mcpt2 expression [60]. However, since Mcpt2 appears to lack enzymatic activity $[28,29]$, its antibacterial effect is probably due to nonenzymatic mechanisms. Mast cells have also been implicated in the host defense against various toxins produced by venomous animals [61], and there is evidence that chymase (Mcpt4) can account for some of these effects [62]. To date, the potential role of chymase in viral infections has not been evaluated. Further, the possible effects of pharmacological chymase inhibition on host defense mechanisms remain to be explored. 


\section{Chymase in Pulmonary Inflammation}

There is currently a wealth of evidence supporting a detrimental role for mast cells in asthma, both from clinical studies and animal experimentation approaches [reviewed in 63-66]. Hence, it would be reasonable to assume that chymase could account, at least to some extent, for such effects. However, somewhat unexpectedly, evidence has accumulated to suggest that chymase in fact has a protective role in asthma. This is supported by evidence from clinical studies where chymase positivity has been correlated with preserved lung function $[67,68]$. In addition, when evaluating $\mathrm{Mcpt} 4^{-/-}$mice in two models for asthma, it was revealed that the absence of Mcpt 4 resulted in elevated airway reactivity and increased eosinophil infiltration [40, 69]. Mechanistically, it has been suggested that Mcpt 4 alleviates airway inflammation by degrading IL-33 [40] or IL-13 [70]. Based on these findings it would be expected that pharmacological chymase inhibition would result in worsened outcome in asthma models. However, it was demonstrated that chymase inhibition in fact had a dampening effect on airway responses in rat and sheep models for allergic airway inflammation [71]. Although these findings are in seeming discrepancy, it should be noted that the chymase inhibitor used (RWJ355871) has dual specificity for chymase and cathepsin G (Table 2). Hence, it cannot be excluded that the beneficial effect of this chymase inhibitor is due to its effects on cathepsin $\mathrm{G}$ rather than on chymase. To firmly establish this issue, it would be warranted to perform studies where more selective chymase inhibitors are assessed in animal models of asthma. Chymase inhibition has also been shown to dampen airway inflammation induced by bacterial lipopolysaccharide [72] and in a silicosis model [73]. In the latter study, chymase inhibition also reduced the lung fibrosis. In line with these findings, the absence of chymase was associated with less inflammatory responses in a bleomycin-induced lung fibrosis model [74], and the latter condition was also improved by pharmacological chymase inhibition [75].

\section{Chymase in Autoimmune Settings}

There is both clinical and experimental evidence from mast cell-deficient mice indicating an aggravating impact of mast cells in arthritis [76]. Intriguingly, whereas mast cells were redundant in passively induced experimental arthritis, they were shown to contribute profoundly in antigen-induced disease [77]. Mechanistically, there is some evidence to suggest that mast cell chymases can contribute to the pathology in such settings. Magnusson et al. [78] showed that animals lacking Mcpt4 exhibited a milder course of disease in collagen-induced arthritis than did the corresponding wild-type counterparts. Moreover, it was shown more recently that also Mcpt5 can contribute to experimental arthritis, as shown in models where arthritis was induced either by transfer of $\mathrm{K} / \mathrm{BxN}$ serum or by meBSA/IL-1 $\beta$ [79]. However, it should be kept in mind that Mcpt5 has no known functional homologue in humans (see "Chymases and chymase knockouts"), and the bearing of this finding on human arthritis is thus not clear. Chymase has also been reported to contribute to the pathology of experimental autoimmune encephalomyelitis, a model for autoimmune multiple sclerosis [80].

\section{Chymase in Cardiovascular Conditions}

It has been recognized for a long time that mast cell chymase can have an impact on various cardiovascular conditions. A hallmark finding that boosted this area of research was the finding that heart chymase can cleave angiotensin (Ang) I to generate the potent pressor Ang II [45], i.e. having overlapping activity with that of angiotensin-converting enzyme (ACE). Based on this finding, a number of studies have been conducted where the effects of pharmacological chymase inhibition on Ang II formation have been studied. In a hallmark study it was demonstrated that chronic ACE inhibition did not repress Ang II levels in the cardiac interstitial fluid, indicating the presence of non-ACE-dependent Ang II-generating activity. Intriguingly, chymase inhibition blocked such Ang II-forming activity in mast cell-sufficient but not in mast cell-deficient mice, suggesting that chymase accounts for ACE-independent Ang II generation within the cardiac tissue [81]. In further support for this notion, the knockout of ACE resulted in abrogated Ang II formation within the circulation but failed to suppress cardiac Ang II levels [82].

Considering that chymase has the capacity to generate Ang II, it would appear likely that chymase repression can lead to reduced blood pressure. Indeed, there are studies in various animal models showing that chymase inhibitors can cause reduced blood pressure in response to various triggers [83-85]. Based on these animal studies, it is reasonable to assume that chymase inhibition could potentially have the effect to lower blood pressure in humans. However, two recent clinical studies evaluating 
BAY 1142524 (fulacimstat) did not reveal any significant effects of chymase inhibition on basal blood pressure [86, 87], although the drugs used were proven to be safe and well tolerated.

In addition to its role in Ang II formation, there is evidence that chymase has an important role in generation of the potent pressor endothelin-1 (ET-1) from big ET-1. This is supported by reduced ET-1 formation and increase in blood pressure in $\mathrm{Mcpt}^{-/-}$animals in response to administration of big ET-1 (the precursor for ET-1) $[54,85]$. In agreement with a crucial function for chymase in this process, ET-1 generation (from big ET-1) was blocked by the chymase inhibitors TY51469 or Suc-ValPro-Phe $(\mathrm{P})(\mathrm{OPh})(2)[54,88]$.

There is also evidence that chymase can have a profound impact on cardiac dysfunction following tissue injury, independently of effects on regulating blood pressure. In one study it was shown that the absence of Mcpt4 was associated with reduced cardiac dysfunction after myocardial infarction, and it was proposed that Mcpt4 deficiency results in increased cardiomyocyte survival [89]. These findings are in agreement with other studies where chymase Mcpt4 was shown to promote cell death and cardiac remodeling after mycoardial infarction [90] and where chymase inhibition resulted in improved cardiac function following myocardial infarction in hamsters [81]. A detrimental function of chymase during heart infarction was also seen in a study where permanent myocardial infarction was induced. In this study, the absence of chymase Mcpt4 led to substantially enhanced survival and cardiac function [91]. In line with these findings, there is a massive documentation revealing protective effects of chymase inhibition in various settings of cardiovascular injury, including myocardial ischemia-reperfusion injury [92], vascular dysfunction in strokeprone rats [93], cardiac fibrosis [94, 95], inflammation after acute myocardial ischemia/reperfusion [95], cardiomyocyte function in dogs with isolated mitral regurgitation [96], cardiac function after left ventricular repair in rats [97], progression to heart failure after autoimmune myocarditis in rats [98], as well as in many other settings of cardiac pathology [99-105]. Based on these findings, it has been proposed that chymase could represent a novel pharmacological target for treatment of cardiovascular disease [reviewed in 106, 107], and ongoing clinical trials are aiming at evaluating this concept.

There is extensive documentation suggesting that chymase can modify lipoproteins (high- and low-density lipoproteins) [108] such that atherosclerotic progression is promoted. In support of this, the genetic ablation of Mcpt4 has been associated with reduced atherosclerotic lesions in apolipoprotein E-deficient mice [109]. In addition, pharmacological inhibition of chymase with RO5066852 was shown to reduce atherosclerotic progression in apolipoprotein E-deficient mice [110]. It has also been shown that chymase promotes the generation of abdominal aortic aneurysms, as shown both by evaluating chymase (Mcpt4)-deficient animals [111] and by using the chymase inhibitors ASB17061 [112] and NK3201 [113].

\section{Chymase in Steatohepatitis/Liver Pathology}

There are several studies showing that chymase inhibition has a substantial beneficial impact on the development of steatohepatitis, as shown in animal models where the condition is induced by different pathogenic diets [114-116]. Chymase inhibition has also been shown to have beneficial effects in acute liver failure in hamsters [117] and in tetrachloride-induced liver fibrosis [118].

\section{Chymase in Inflammatory Kidney Disease}

There are several indications that chymase can affect the outcome of inflammatory kidney disease, but the impact of chymase seems to depend strongly on the exact condition. In immune complex-mediated glomerulonephritis, Mcpt 4 chymase was shown to contribute to the inflammation and fibrosis, and the absence of Mcpt4 led to lower levels of various pathogenic factors, including Ang II, collagen 1, TNF and MCP-1/CCL2 [119]. In support of a role for chymase in generating Ang II in the context of kidney pathology, pharmacological chymase inhibition was shown to suppress renal Ang II formation in diabetic mice [120] and in mice treated with Ang I (precursor of Ang II) [84]. Additionally, chymase inhibition has been shown to protect against albuminuria in diabetic mice [121] and rats [122], to protect against diabetes-induced oxidative stress and renal dysfunction in hamsters [123] and to confer pancreatic islet protection in experimental diabetes [124]. In line with a detrimental impact of chymase in kidney pathology, Mcpt4 was shown to partly account for the inflammation induced by partial ureteral obstruction [125]. In that study it was observed that Mcpt4 promoted kidney hyper/hypotrophy, development of fibrosis, CCL2 secretion and $\alpha$-smooth muscle actin expression [125]. In contrast, when kidney inflammation was induced by unilateral ureteral obstruction, chymase was shown to a have a protective function [32]. Here, increased 
fibrosis, $\alpha$-smooth muscle actin, collagen deposition, CCL 2 and TGF- $\beta$ were seen in animals lacking Mcpt 4 expression, i.e. in sharp contrast to the findings in the partial ureteral obstruction setting. The reasons behind these apparent discrepancies are not entirely clear. However, it was reasoned that these differences could be explained by the specific pathophysiological phenotypes associated with the respective types of lesions, and possibly related to different disease kinetics of the models [125]. A protective function for chymase has also been seen in ischemic kidney injury, where Mcpt4 was shown to limit neutrophil recruitment and activation [126]. It was suggested that chymase exerted this role by modifying the surface expression of CD11b integrin and P/E-selectin [126].

\section{Chymase in Regulation of the Coagulation System}

There is evidence suggesting that chymase could be involved in the regulation of certain blood coagulation parameters. It was shown in an early study that purified chymase Mcpt4 efficiently degrades thrombin, thereby abolishing its enzymatic activity [46]. This was supported by studies showing that the knockout of Mcpt4 abolished the ability of mast cells to proteolytically inactivate thrombin [23]. In further agreement with this, a more recent study demonstrated that Mcpt4 has a major function in limiting thrombin-induced skin inflammation in vivo [47]. It has also been shown that chymase has the capacity to regulate plasmin activity [127]. Further, it was shown in a recent study that chymase, in vivo, has a role in regulating FXIIIA (transglutaminase) activity [128]. Altogether, these findings suggest that chymase can regulate the coagulation cascade at various levels, potentially affecting blood coagulation. Indeed, Mcpt 4 deficiency has recently been shown to cause reduced bleeding times during experimental sepsis [128]. However, considering that chymase is generally found outside of the circulation, it appears likely that chymase may predominantly affect extravascular coagulation events.

\section{The Role of Chymase in Regulating Inflammatory Cell Recruitment}

There is substantial evidence that chymase has the ability to promote inflammatory cell recruitment in various settings. This is, firstly, supported by experiments in which administration of purified/recombinant chymase in different animal models has been shown to cause the accumula- tion of various inflammatory cell types, including eosinophils [129, 130], neutrophils [73, 130, 131], lymphocytes [130] and macrophages [130]. In support of this, various chymase inhibitors have been demonstrated to suppress the accumulation of leukocytes under different inflammatory conditions. For example, chymase inhibition has been shown to attenuate eosinophilia $[132,133]$, to inhibit neutrophil influx in various inflammatory settings [71-73, 95] and to reduce monocyte/macrophage recruitment [93, 134]. It has additionally been demonstrated that chymase inhibition can dampen inflammatory responses in a rat model of inflammatory bowel disease [135].

At present it is not entirely clear by what mechanism chymase causes leukocyte recruitment. However, there is evidence suggesting that chymase has a major role in degrading tight junction proteins $[53,136]$, and a plausible scenario could thus be that such chymase-dependent degradation of cell-cell contacts could be an important factor in promoting the migration of inflammatory cells from the circulation to sites of tissue injury. In agreement with this notion, chymase has been shown to enhance paracellular permeability of the gut epithelium, both at baseline conditions [136] and during anaphylaxis [137]. Chymase has also been shown to cause increased microvascular leakage in skin [138]. On a similar angle, chymase has shown to cleave hemidesmosome proteins in the context of autoimmune bullous pemphigoid, thereby contributing to the inflammation seen in this condition [36].

In seeming discrepancy with these findings (see discussion under "Biological functions of chymases: general considerations"), it has been shown that chymase may also exert anti-inflammatory properties, e.g. by degrading proinflammatory alarmins [52], IL-33 [40,69] or IL-13 [70]. Further, chymase has been shown to protect from posttraumatic spinal cord damage, most likely by degrading proinflammatory cytokines [139]. Moreover, the absence of Mcpt4 led to increased scar formation under this condition [140]. Also in posttraumatic brain inflammation, chymase has been shown to have a protective role, by reducing brain inflammation [141].

\section{Chymase in Skin Pathologies}

Chymase-expressing mast cells are abundant in skin, and it is therefore reasonable to assume that chymase could have a significant impact on pathologies of this organ. Indeed, there are numerous studies in support of this notion. In a scleroderma model (tight skin mice; 
Tsk), selective upregulation of chymase Mcpt4 was seen [142] and pharmacological chymase inhibition by SUNC8257 was shown to dampen the pathology significantly [143]. It was proposed that the beneficial effect of chymase inhibition was due to blunted generation of profibrotic TGF- $\beta$. It has also been shown that chymase inhibition (by SUN-C8257 or SUN13834) improves atopic dermatitis-like skin lesions in NC/Nga mice [129, 133, 144]. Further, it was shown in a burn-induced injury model that both Mcpt 4 and Mcpt5 contribute profoundly to the pathology [53]. Chymase has also been shown to be crucial for limiting thrombin-induced skin inflammation [47].

\section{Chymase in Adhesions after Surgery}

Formations of adhesions are serious adverse affects associated with surgery. Several animal experimental studies have revealed that mast cell chymase can contribute to this condition, as shown by attenuated peritoneal adhesion formation after administration of Suc-Val-Pro$\mathrm{PheP}(\mathrm{OPh}) 2$ in rat [145], hamster [146] and canine [147] models. Peritoneal adhesion formation was also inhibited by using the TY-51184 and NK3201 chymase inhibitors in hamster models $[148,149]$. However, a role for chymase in adhesion formation has not been confirmed by studies in chymase-deficient animals.

\section{Chymase in the Regulation of Homeostasis}

It is generally thought that biological effects of the mast cell granule proteases are seen under inflammatory conditions where mast cells have been activated, by IgEmediated or other mechanisms. However, there is accumulating evidence suggesting that chymase can exert biological effects even in conditions were mast cells are not overtly activated, i.e. to affect body homeostasis. In one study it was shown that the absence of Mcpt4 caused decreased intestinal permeability at baseline conditions, and it was shown that the absence of Mcpt4 led to increased expression of the tight junction protein claudin-3 [136]. Hence, this suggests that chymase can enhance epithelial permeability under homeostatic conditions by degrading tight junctions. Notably, this is in agreement with a study showing that Mcpt 4 can degrade claudin-4 during skin inflammation caused by burn injury [53], and with an earlier study where it was demonstrated that infusion of chymase to the cranial mesenteric artery caused in- creased gut permeability in rats [150]. There is also evidence that the absence of chymase $\mathrm{Mcpt} 4$ results in an age-dependent increase in bone mass in female mice under baseline conditions, i.e. suggesting that Mcpt4 has a homeostatic impact on the regulation of bone metabolism [151]. Finally, there is evidence to suggest that chymase has a role in the regulation of homeostatic extracellular matrix deposition, as shown by an age-dependent, excessive accumulation of collagen and fibronectin in mice lacking Mcpt4 [35].

\section{Concluding Remarks and Future Directions}

Research conducted over the last decades has provided considerable insight into the biological function of chymase. In particular, the use of chymase knockout animals and the use of selective chymase inhibitors have made it possible to elucidate the in vivo impact of chymase in diverse pathological, but also homeostatic, conditions. Intriguingly, the gathered knowledge from these efforts suggests that chymase has a highly complex role in regulating pathological processes, ranging from protective functions in some cases to being detrimental in others (Table 3). To add further complexity, chymase can even have opposing functions in a given condition, depending on the methodology/tools adapted. So, can we exploit this knowledge for medical purposes? Clearly, in cases where there is a well-documented detrimental impact of chymase, chymase inhibition could be of therapeutic significance. The most notable example of the latter is cardiac dysfunction after heart injury, where a wealth of evidence from various animal experimental models and from evaluating a wide range of chymase inhibitors indicates that chymase inhibition can alleviate the pathology in a profound way. Indeed, clinical trials to assess this notion are currently under way. On the contrary, in cases where chymase has a proven beneficial role, it is conceivable that recombinant chymase could be used as a biological drug. However, since chymase carries a high positive charge, it may be anticipated that its pharmacological properties are suboptimal. Given the range of additional pathologies where chymase has been implicated (Table 3), it is likely that chymase inhibition will be assessed for beneficial effects in a range of novel clinical settings in the near future. It is also likely that upcoming research will provide a more detailed insight into the exact mechanism of chymase action under diverse pathological situations. For example, it will be important to gain more knowledge of the in vivo substrates for chymase under various pathological 
settings, and also under different phases of a given pathological process. Most likely, such efforts will provide a more comprehensive picture of the exact biological function of chymase, knowledge that will aid in exploiting chymase for therapeutic or diagnostic purposes.

\section{Acknowledgments}

The author is grateful to Uppsala University for providing excellent facilities and infrastructure for writing this review article.

\section{Disclosure Statement}

The author has no conflict of interest in relation to this work.

\section{Funding Sources}

The author is sponsored by grants from the Swedish Heart and Lung Foundation, the Swedish Research Council, the Swedish Cancer Foundation, the Swedish Childhood Cancer Fund and Knut and Alice Wallenberg Foundation.

\section{Statement of Ethics}

The author has considered ethical aspects related to this review article.

\section{Author Contributions}

G.P. performed all of the work associated with this review article.

\section{References}

1 Metz M, Maurer M. Mast cells - key effector cells in immune responses. Trends Immunol. 2007 May;28(5):234-41.

2 Voehringer D. Protective and pathological roles of mast cells and basophils. Nat Rev Immunol. 2013 May;13(5):362-75.

3 Marichal T, Tsai M, Galli SJ. Mast cells: potential positive and negative roles in tumor biology. Cancer Immunol Res. 2013 Nov;1(5):269-79.

4 Galli SJ, Nakae S, Tsai M. Mast cells in the development of adaptive immune responses. Nat Immunol. 2005 Feb;6(2):135-42.

5 Marshall JS. Mast-cell responses to pathogens. Nat Rev Immunol. 2004 Oct;4(10):787-99.

6 Marshall JS, Portales-Cervantes L, Leong E. Mast Cell Responses to Viruses and Pathogen Products. Int J Mol Sci. 2019 Aug; 20(17):20.

7 Johnzon CF, Rönnberg E, Pejler G. The Role of Mast Cells in Bacterial Infection. Am J Pathol. 2016 Jan;186(1):4-14.

8 Wernersson S, Pejler G. Mast cell secretory granules: armed for battle. Nat Rev Immunol. 2014 Jul;14(7):478-94.

9 Pejler G, Rönnberg E, Waern I, Wernersson S. Mast cell proteases: multifaceted regulators of inflammatory disease. Blood. 2010 Jun; 115(24):4981-90.

10 Pejler G, Åbrink M, Ringvall M, Wernersson S. Mast cell proteases. Adv Immunol. 2007;95: 167-255.

11 Motakis E, Guhl S, Ishizu Y, Itoh M, Kawaji $\mathrm{H}$, de Hoon $\mathrm{M}$, et al.; FANTOM consortium. Redefinition of the human mast cell transcriptome by deep-CAGE sequencing. Blood. 2014 Apr;123(17):e58-67.

12 Dwyer DF, Barrett NA, Austen KF; Immunological Genome Project Consortium. Expression profiling of constitutive mast cells reveals a unique identity within the immune system. Nat Immunol. 2016 Jul;17(7):878-87.
13 Akula S, Paivandy A, Fu Z, Thorpe M, Pejler G, Hellman L. Quantitative In-Depth Analysis of the Mouse Mast Cell Transcriptome Reveals Organ-Specific Mast Cell Heterogeneity. Cells. 2020 Jan;9(1):9.

14 Lützelschwab C, Pejler G, Aveskogh M, Hellman L. Secretory granule proteases in rat mast cells. Cloning of 10 different serine proteases and a carboxypeptidase A from various rat mast cell populations. J Exp Med. 1997 Jan; 185(1):13-29.

15 Schwartz LB, Riedel C, Caulfield JP, Wasserman SI, Austen KF. Cell association of complexes of chymase, heparin proteoglycan, and protein after degranulation by rat mast cells. J Immunol. 1981 Jun;126(6):2071-8.

16 Schwartz LB, Irani AM, Roller K, Castells MC, Schechter NM. Quantitation of histamine, tryptase, and chymase in dispersed human $\mathrm{T}$ and TC mast cells. J Immunol. 1987 Apr; 138(8):2611-5.

17 Xing W, Austen KF, Gurish MF, Jones TG. Protease phenotype of constitutive connective tissue and of induced mucosal mast cells in mice is regulated by the tissue. Proc Natl Acad Sci USA. 2011 Aug; 108(34): 14210-5.

18 Åbrink M, Grujic M, Pejler G. Serglycin is essential for maturation of mast cell secretory granule. J Biol Chem. 2004 Sep;279(39): 40897-905.

19 Forsberg E, Pejler G, Ringvall M, Lunderius C, Tomasini-Johansson B, Kusche-Gullberg $\mathrm{M}$, et al. Abnormal mast cells in mice deficient in a heparin-synthesizing enzyme. Nature. 1999 Aug;400(6746):773-6.

20 Braga T, Grujic M, Lukinius A, Hellman L, Åbrink M, Pejler G. Serglycin proteoglycan is required for secretory granule integrity in mucosal mast cells. Biochem J. 2007 Apr; 403(1):49-57.
21 Wastling JM, Knight P, Ure J, Wright S, Thornton EM, Scudamore CL, et al. Histochemical and ultrastructural modification of mucosal mast cell granules in parasitized mice lacking the beta-chymase, mouse mast cell protease- 1 . Am J Pathol. 1998 Aug;153(2):491-504.

22 Abonia JP, Friend DS, Austen WG Jr, Moore FD Jr, Carroll MC, Chan R, et al. Mast cell protease 5 mediates ischemia-reperfusion injury of mouse skeletal muscle. J Immunol. 2005 Jun;174(11):7285-91.

23 Tchougounova E, Pejler G, Åbrink M. The chymase, mouse mast cell protease 4 , constitutes the major chymotrypsin-like activity in peritoneum and ear tissue. A role for mouse mast cell protease 4 in thrombin regulation and fibronectin turnover. J Exp Med. 2003 Aug;198(3):423-31.

24 Hellman L, Thorpe M. Granule proteases of hematopoietic cells, a family of versatile inflammatory mediators - an update on their cleavage specificity, in vivo substrates, and evolution. Biol Chem. 2014 Jan;395(1):15-49.

25 Andersson MK, Enoksson M, Gallwitz M, Hellman L. The extended substrate specificity of the human mast cell chymase reveals a serine protease with well-defined substrate recognition profile. Int Immunol. 2009 Jan; 21(1):95-104.

26 Andersson MK, Karlson U, Hellman L. The extended cleavage specificity of the rodent beta-chymases rMCP-1 and mMCP-4 reveal major functional similarities to the human mast cell chymase. Mol Immunol. 2008 Feb; 45(3):766-75.

27 Andersson MK, Pemberton AD, Miller HR Hellman L. Extended cleavage specificity of mMCP-1, the major mucosal mast cell protease in mouse-high specificity indicates high substrate selectivity. Mol Immunol. 2008 May;45(9):2548-58. 
28 Pemberton $\mathrm{AD}$, Brown JK, Wright $\mathrm{SH}$, Knight PA, McPhee ML, McEuen AR, et al. Purification and characterization of mouse mast cell proteinase- 2 and the differential expression and release of mouse mast cell proteinase- 1 and -2 in vivo. Clin Exp Allergy. 2003 Jul;33(7):1005-12.

29 Pemberton AD, Wright SH, Knight PA, Miller HR. Anaphylactic release of mucosal mast cell granule proteases: role of serpins in the differential clearance of mouse mast cell proteases-1 and -2. J Immunol. 2006 Jan;176(2): 899-904.

30 Kunori Y, Koizumi M, Masegi T, Kasai H, Kawabata H, Yamazaki Y, et al. Rodent alphachymases are elastase-like proteases. Eur J Biochem. 2002 Dec;269(23):5921-30.

31 Vartio T, Seppä H, Vaheri A. Susceptibility of soluble and matrix fibronectins to degradation by tissue proteinases, mast cell chymase and cathepsin G. J Biol Chem. 1981 Jan; 256(1):471-7.

32 Beghdadi W, Madjene LC, Claver J, Pejler G, Beaudoin L, Lehuen A, et al. Mast cell chymase protects against renal fibrosis in murine unilateral ureteral obstruction. Kidney Int. 2013 Aug;84(2):317-26.

33 Saarinen J, Kalkkinen N, Welgus HG, Kovanen PT. Activation of human interstitial procollagenase through direct cleavage of the Leu83-Thr84 bond by mast cell chymase. J Biol Chem. 1994 Jul;269(27):1813440.

34 Fang KC, Raymond WW, Lazarus SC, Caughey GH. Dog mastocytoma cells secrete a $92-\mathrm{kD}$ gelatinase activated extracellularly by mast cell chymase. J Clin Invest. 1996 Apr; 97(7):1589-96.

35 Tchougounova E, Lundequist A, Fajardo I, Winberg JO, Abrink M, Pejler G. A key role for mast cell chymase in the activation of promatrix metalloprotease- 9 and pro-matrix metalloprotease-2. J Biol Chem. 2005 Mar; 280(10):9291-6.

36 Lin L, Bankaitis E, Heimbach L, Li N, Abrink M, Pejler G, et al. Dual targets for mouse mast cell protease- 4 in mediating tissue damage in experimental bullous pemphigoid. J Biol Chem. 2011 Oct;286(43):37358-67.

37 Groschwitz KR, Wu D, Osterfeld H, Ahrens R, Hogan SP. Chymase-mediated intestinal epithelial permeability is regulated by a protease-activating receptor/matrix metalloproteinase-2-dependent mechanism. Am J Physiol Gastrointest Liver Physiol. 2013 Mar; 304(5):G479-89.

38 Zhao W, Oskeritzian CA, Pozez AL, Schwartz LB. Cytokine production by skin-derived mast cells: endogenous proteases are responsible for degradation of cytokines. J Immunol. 2005 Aug;175(4):2635-42.

$39 \mathrm{Fu} \mathrm{Z}$, Thorpe M, Alemayehu R, Roy A, Kervinen J, de Garavilla L, et al. Highly Selective Cleavage of Cytokines and Chemokines by the Human Mast Cell Chymase and Neutrophil Cathepsin G. J Immunol. 2017 Feb; 198(4):1474-83.
40 Waern I, Lundequist A, Pejler G, Wernersson S. Mast cell chymase modulates IL-33 levels and controls allergic sensitization in dustmite induced airway inflammation. Mucosal Immunol. 2013 Sep;6(5):911-20.

41 Mizutani H, Schechter N, Lazarus G, Black RA, Kupper TS. Rapid and specific conversion of precursor interleukin 1 beta (IL-1 beta) to an active IL-1 species by human mast cell chymase. J Exp Med. 1991 Oct;174(4): 821-5.

42 Omoto Y, Tokime K, Yamanaka K, Habe K, Morioka T, Kurokawa I, et al. Human mast cell chymase cleaves pro-IL-18 and generates a novel and biologically active IL-18 fragment. J Immunol. 2006 Dec;177(12):8315-9.

43 Piliponsky AM, Chen CC, Rios EJ, Treuting PM, Lahiri A, Abrink M, et al. The chymase mouse mast cell protease 4 degrades TNF, limits inflammation, and promotes survival in a model of sepsis. Am J Pathol. 2012 Sep; 181(3):875-86.

44 Berahovich RD, Miao Z, Wang Y, Premack B, Howard MC, Schall TJ. Proteolytic activation of alternative CCR1 ligands in inflammation. J Immunol. 2005 Jun;174(11):7341-51.

45 Urata H, Kinoshita A, Misono KS, Bumpus FM, Husain A. Identification of a highly specific chymase as the major angiotensin IIforming enzyme in the human heart [published erratum appears in J Biol Chem 1991 Jun 25;266(18):12114]. J Biol Chem. 1990 Dec;265(36):22348-57.

46 Pejler G, Karlström A. Thrombin is inactivated by mast cell secretory granule chymase. I Biol Chem. 1993 Jun;268(16):11817-22.

47 Suender CA, Leist M, Åbrink M, Valentin P, Geldmacher A, Steinhoff M, et al. Mast cells are critical for the limitation of thrombin-induced skin inflammation. Exp Dermatol. 2018 Jan;27(1):50-7.

48 Taipale J, Lohi J, Saarinen J, Kovanen PT, Keski-Oja J. Human mast cell chymase and leukocyte elastase release latent transforming growth factor-beta 1 from the extracellular matrix of cultured human epithelial and endothelial cells. J Biol Chem. 1995 Mar;270(9):4689-96.

49 Wang Y, Shiota N, Leskinen MJ, Lindstedt KA, Kovanen PT. Mast cell chymase inhibits smooth muscle cell growth and collagen expression in vitro: transforming growth factorbeta1-dependent and -independent effects. Arterioscler Thromb Vasc Biol. 2001 Dec; 21(12):1928-33.

50 Cho SH, Lee SH, Kato A, Takabayashi T, Kulka M, Shin SC, et al. Cross-talk between human mast cells and bronchial epithelial cells in plasminogen activator inhibitor-1 production via transforming growth factor- $\beta 1$. Am J Respir Cell Mol Biol. 2015 Jan;52(1):88-95.

51 Caughey GH, Leidig F, Viro NF, Nadel JA. Substance $P$ and vasoactive intestinal peptide degradation by mast cell tryptase and chymase. J Pharmacol Exp Ther. 1988 Jan;244(1): 133-7.

52 Roy A, Ganesh G, Sippola H, Bolin S, Sawesi $\mathrm{O}$, Dagälv A, et al. Mast cell chymase degrades the alarmins heat shock protein 70 , biglycan, HMGB1, and interleukin-33 (IL-33) and limits danger-induced inflammation. J Biol Chem. 2014 Jan;289(1):237-50.

53 Bankova LG, Lezcano C, Pejler G, Stevens RL, Murphy GF, Austen KF, et al. Mouse mast cell proteases 4 and 5 mediate epidermal injury through disruption of tight junctions. J Immunol. 2014 Mar;192(6):2812-20.

54 Houde M, Jamain MD, Labonté J, Desbiens L, Pejler G, Gurish M, et al. Pivotal role of mouse mast cell protease 4 in the conversion and pressor properties of Big-endothelin-1. J Pharmacol Exp Ther. 2013 Jul;346(1):317.

55 Guillabert A, Wittamer V, Bondue B, Godot $\mathrm{V}$, Imbault $\mathrm{V}$, Parmentier $\mathrm{M}$, et al. Role of neutrophil proteinase 3 and mast cell chymase in chemerin proteolytic regulation. J Leukoc Biol. 2008 Dec;84(6):1530-8.

56 Schiemann F, Grimm TA, Hoch J, Gross R, Lindner B, Petersen F, et al. Mast cells and neutrophils proteolytically activate chemokine precursor CTAP-III and are subject to counterregulation by $\mathrm{PF}-4$ through inhibition of chymase and cathepsin G. Blood. 2006 Mar;107(6):2234-42.

57 Pejler G. The emerging role of mast cell proteases in asthma. Eur Respir J. 2019 Oct;54(4): 54.

58 Knight PA, Wright SH, Lawrence CE, Paterson YY, Miller HR. Delayed expulsion of the nematode Trichinella spiralis in mice lacking the mucosal mast cell-specific granule chymase, mouse mast cell protease-1. J Exp Med. 2000 Dec;192(12):1849-56.

59 Gendrin C, Shubin NJ, Boldenow E, et al. Mast cell chymase decreases the severity of group B Streptococcus infections. J Allergy Clin Immunol. 2018;142:120-129.e126.

60 Orinska Z, Maurer M, Mirghomizadeh F, Bulanova E, Metz M, Nashkevich N, et al. IL-15 constrains mast cell-dependent antibacterial defenses by suppressing chymase activities. Nat Med. 2007 Aug;13(8):927-34

61 Metz M, Piliponsky AM, Chen CC, Lammel V, Abrink M, Pejler G, et al. Mast cells can enhance resistance to snake and honeybee venoms. Science. 2006 Jul;313(5786):526-30.

62 Akahoshi M, Song CH, Piliponsky AM, Metz M, Guzzetta A, Abrink M, et al. Mast cell chymase reduces the toxicity of Gila monster venom, scorpion venom, and vasoactive intestinal polypeptide in mice. J Clin Invest. 2011 Oct;121(10):4180-91.

63 Bradding P, Arthur G. Mast cells in asthma state of the art. Clin Exp Allergy. 2016 Feb; 46(2):194-263.

64 Galli SJ, Tsai M. IgE and mast cells in allergic disease. Nat Med. 2012 May;18(5):693-704

65 Erjefält JS. Mast cells in human airways: the culprit? Eur Respir Rev. 2014 Sep;23(133): 299-307.

66 Andersson C, Tufvesson E, Diamant Z, Bjermer L. Revisiting the role of the mast cell in asthma. Curr Opin Pulm Med. 2016 Jan; 22(1):10-7. 
67 Balzar S, Chu HW, Strand M, Wenzel S. Relationship of small airway chymase-positive mast cells and lung function in severe asthma. Am J Respir Crit Care Med. 2005 Mar;171(5): 431-9.

68 Zanini A, Chetta A, Saetta M, Baraldo S, D'Ippolito R, Castagnaro A, et al. Chymasepositive mast cells play a role in the vascular component of airway remodeling in asthma. J Allergy Clin Immunol. 2007 Aug; 120(2): 329-33.

69 Waern I, Jonasson S, Hjoberg J, Bucht A, Abrink M, Pejler G, et al. Mouse mast cell protease 4 is the major chymase in murine airways and has a protective role in allergic airway inflammation. J Immunol. 2009 Nov; 183(10):6369-76

70 Sugimoto K, Kudo M, Sundaram A, Ren X, Huang K, Bernstein X, et al. The av $\beta 6$ integrin modulates airway hyperresponsiveness in mice by regulating intraepithelial mast cells. J Clin Invest. 2012 Feb;122(2):748-58.

71 Maryanoff BE, de Garavilla L, Greco MN, Haertlein BJ, Wells GI, Andrade-Gordon P, et al. Dual inhibition of cathepsin G and chymase is effective in animal models of pulmonary inflammation. Am J Respir Crit Care Med. 2010 Feb;181(3):247-53.

72 de Garavilla L, Greco MN, Sukumar N, Chen ZW, Pineda AO, Mathews FS, et al. A novel, potent dual inhibitor of the leukocyte proteases cathepsin $G$ and chymase: molecular mechanisms and anti-inflammatory activity in vivo. J Biol Chem. 2005 May;280(18): 18001-7.

73 Takato H, Yasui M, Ichikawa Y, Waseda Y, Inuzuka K, Nishizawa $Y$, et al. The specific chymase inhibitor TY-51469 suppresses the accumulation of neutrophils in the lung and reduces silica-induced pulmonary fibrosis in mice. Exp Lung Res. 2011 Mar;37(2):101-8.

74 Reber LL, Daubeuf F, Pejler G, Abrink M, Frossard N. Mast cells contribute to bleomycin-induced lung inflammation and injury in mice through a chymase/mast cell protease 4-dependent mechanism. J Immunol. 2014 Feb;192(4):1847-54.

75 Sakaguchi M, Takai S, Jin D, Okamoto Y, Muramatsu M, Kim S, et al. A specific chymase inhibitor, NK3201, suppresses bleomycin-induced pulmonary fibrosis in hamsters. Eur J Pharmacol. 2004 Jun;493(1-3):173-6.

76 Rivellese F, Nerviani A, Rossi FW, Marone G, Matucci-Cerinic M, de Paulis A, et al. Mast cells in rheumatoid arthritis: friends or foes? Autoimmun Rev. 2017 Jun;16(6):557-63.

77 Schubert N, Dudeck J, Liu P, Karutz A, Speier S, Maurer M, et al. Mast cells promote T cell driven antigen-induced arthritis despite being dispensable in $\mathrm{T}$ cell bypassing antibodyinduced arthritis. Arthritis Rheumatol. 2015 Apr;67(4):903-13.

78 Magnusson SE, Pejler G, Kleinau S, Abrink M. Mast cell chymase contributes to the antibody response and the severity of autoimmune arthritis. FASEB J. 2009 Mar;23(3): $875-82$.
79 Stevens RL, McNeil HP, Wensing LA, Shin K, Wong GW, Hansbro PM, et al. Experimental Arthritis Is Dependent on Mouse Mast Cell Protease-5. J Biol Chem. 2017 Mar;292(13): 5392-404.

80 Desbiens L, Lapointe C, Gharagozloo M, Mahmoud S, Pejler G, Gris D, et al. Significant contribution of mouse mast cell protease 4 in early phases of experimental autoimmune encephalomyelitis. Mediators Inflamm. 2016; 2016:9797021.

81 Wei CC, Hase N, Inoue Y, Bradley EW, Yahiro E, Li M, et al. Mast cell chymase limits the cardiac efficacy of Ang I-converting enzyme inhibitor therapy in rodents. J Clin Invest. 2010 Apr;120(4):1229-39.

82 Wei CC, Tian B, Perry G, Meng QC, Chen YF, Oparil S, et al. Differential ANG II generation in plasma and tissue of mice with decreased expression of the ACE gene. Am J Physiol Heart Circ Physiol. 2002 Jun;282(6):H2254-8.

83 Devarajan S, Yahiro E, Uehara Y, Habe S, Nishiyama A, Miura S, et al. Depressor effect of chymase inhibitor in mice with high salt-induced moderate hypertension. Am J Physiol Heart Circ Physiol. 2015 Dec; 309(11):H1987-96.

84 Ansary TM, Urushihara M, Fujisawa Y, Nagata $\mathrm{S}$, Urata H, Nakano D, et al. Effects of the selective chymase inhibitor TEI-F00806 on the intrarenal renin-angiotensin system in salt-treated angiotensin I-infused hypertensive mice. Exp Physiol. 2018 Nov;103(11):1524-31.

85 Semaan W, Desbiens L, Houde M, Labonté J, Gagnon H, Yamamoto D, et al. Chymase inhibitor-sensitive synthesis of endothelin-1 (131 ) by recombinant mouse mast cell protease 4 and human chymase. Biochem Pharmacol. 2015 Mar;94(2):91-100.

86 Düngen HD, Kober L, Nodari S, Schou M, Otto C, Becka M, et al. Safety and Tolerability of the Chymase Inhibitor Fulacimstat in $\mathrm{Pa}$ tients With Left Ventricular Dysfunction After Myocardial Infarction-Results of the CHIARA MIA 1 Trial. Clin Pharmacol Drug Dev. 2019 Oct;8(7):942-51.

87 Kanefendt F, Thuß U, Becka M, Boxnick S, Berse M, Schultz A, et al. Pharmacokinetics, Safety, and Tolerability of the Novel Chymase Inhibitor BAY 1142524 in Healthy Male Volunteers. Clin Pharmacol Drug Dev. 2019 May;8(4):467-79.

88 Simard E, Jin D, Takai S, Miyazaki M, Brochu I, D'Orléans-Juste P. Chymase-dependent conversion of Big endothelin- 1 in the mouse in vivo. J Pharmacol Exp Ther. 2009 Feb;328(2):540-8.

89 Wang Y, Liu CL, Fang W, Zhang X, Yang C, Li $J$, et al. Deficiency of mouse mast cell protease 4 mitigates cardiac dysfunctions in mice after myocardium infarction. Biochim Biophys Acta Mol Basis Dis. 2019 Jun;1865(6):1170-81.

90 Tejada T, Tan L, Torres RA, Calvert JW, Lambert JP, Zaidi M, et al. IGF-1 degradation by mouse mast cell protease 4 promotes cell death and adverse cardiac remodeling days after a myocardial infarction. Proc Natl Acad Sci USA. 2016 Jun;113(25):6949-54.
91 Houde M, Schwertani A, Touil H, Desbiens L, Sarrhini O, Lecomte R, et al. Mouse mast cell protease 4 deletion protects heart function and survival after permanent myocardial infarction. Front Pharmacol. 2018 Aug; 9:868.

92 Hooshdaran B, Kolpakov MA, Guo X, Miller SA, Wang T, Tilley DG, et al. Dual inhibition of cathepsin $G$ and chymase reduces myocyte death and improves cardiac remodeling after myocardial ischemia reperfusion injury. Basic Res Cardiol. 2017 Sep; 112(6):62.

93 Takai S, Jin D, Chen H, Li W, Yamamoto $\mathrm{H}$, Yamanishi $\mathrm{K}$, et al. Chymase inhibition improves vascular dysfunction and survival in stroke-prone spontaneously hypertensive rats. J Hypertens. 2014 Aug;32(8): 1637-48.

94 Maeda Y, Inoguchi T, Takei R, Hendarto H, Ide $\mathrm{M}$, Inoue $\mathrm{T}$, et al. Chymase inhibition prevents myocardial fibrosis through the attenuation of NOX4-associated oxidative stress in diabetic hamsters. J Diabetes Investig. 2012 Aug;3(4):354-61.

95 Oyamada S, Bianchi C, Takai S, Chu LM, Sellke FW. Chymase inhibition reduces infarction and matrix metalloproteinase- 9 activation and attenuates inflammation and fibrosis after acute myocardial ischemia/reperfusion. J Pharmacol Exp Ther. 2011 Oct;339(1):14351.

96 Pat B, Chen Y, Killingsworth C, Gladden JD, Shi K, Zheng J, et al. Chymase inhibition prevents fibronectin and myofibrillar loss and improves cardiomyocyte function and $\mathrm{LV}$ torsion angle in dogs with isolated mitral regurgitation. Circulation. 2010 Oct; 122(15):1488-95.

97 Kanemitsu H, Takai S, Tsuneyoshi H, Yoshikawa E, Nishina T, Miyazaki M, et al. Chronic chymase inhibition preserves cardiac function after left ventricular repair in rats. Eur J Cardiothorac Surg. 2008 Jan; 33(1):25-31.

98 Palaniyandi SS, Nagai Y, Watanabe K, Ma M, Veeraveedu PT, Prakash P, et al. Chymase inhibition reduces the progression to heart failure after autoimmune myocarditis in rats. Exp Biol Med (Maywood). 2007 Oct; 232(9):1213-21.

99 Jin D, Takai S, Sakaguchi M, Okamoto Y, Muramatsu M, Miyazaki M. An antiarrhythmic effect of a chymase inhibitor after myocardial infarction. J Pharmacol Exp Ther. 2004 May;309(2):490-7.

100 Jin D, Takai S, Yamada M, Sakaguchi M, Kamoshita K, Ishida K, et al. Impact of chymase inhibitor on cardiac function and survival after myocardial infarction. Cardiovasc Res. 2003 Nov; 60(2):413-20.

101 Matsumoto T, Wada A, Tsutamoto T, Ohnishi M, Isono T, Kinoshita M. Chymase inhibition prevents cardiac fibrosis and improves diastolic dysfunction in the progression of heart failure. Circulation. 2003 May; 107(20):2555-8. 
102 Hoshino F, Urata H, Inoue Y, Saito Y, Yahiro E, Ideishi M, et al. Chymase inhibitor improves survival in hamsters with myocardial infarction. J Cardiovasc Pharmacol. 2003 Jan;41 Suppl 1:S11-8.

103 Takai S, Jin D, Sakaguchi M, Katayama S, Muramatsu M, Sakaguchi M, et al. A novel chymase inhibitor, 4-[1-([bis-(4-methylphenyl)-methyl]-carbamoyl)3-(2-ethoxybenzyl)-4-oxo-azetidine-2-yloxy]-benzoic acid (BCEAB), suppressed cardiac fibrosis in cardiomyopathic hamsters. J Pharmacol Exp Ther. 2003 Apr;305(1):17-23.

104 Takai S, Sakonjo H, Fukuda K, Jin D, Sakaguchi M, Kamoshita K, et al. A novel chymase inhibitor, 2-(5-formylamino-6-oxo-2-phenyl-1,6-dihydropyrimidine-1-yl)-N-[[,4-dioxo-1-phenyl-7-(2-pyridyloxy)]2-heptyl] acetamide (NK3201), suppressed intimal hyperplasia after balloon injury. J Pharmacol Exp Ther. 2003 Feb;304(2):841-4.

105 Jin D, Takai S, Yamada M, Sakaguchi M, Miyazaki M. Beneficial effects of cardiac chymase inhibition during the acute phase of myocardial infarction. Life Sci. 2002 Jun; 71(4):437-46.

106 Takai S, Jin D. Improvement of cardiovascular remodelling by chymase inhibitor. Clin Exp Pharmacol Physiol. 2016 Apr;43(4): 387-93.

107 Tojo H, Urata H. Chymase inhibition and cardiovascular protection. Cardiovasc Drugs Ther. 2013 Apr;27(2):139-43.

108 Kovanen PT. Mast cells as potential accelerators of human atherosclerosis - from early to late lesions. Int J Mol Sci. 2019 Sep; 20(18):20.

109 Houde M, Desbiens L, Schwertani A, Pejler G, Iglarz M, D’Orléans-Juste P. Endothelin receptor antagonist macitentan or deletion of mouse mast cell protease 4 delays lesion development in atherosclerotic mice. Life Sci. 2016 Aug; 159:71-5.

110 Bot I, Bot M, van Heiningen SH, van Santbrink PJ, Lankhuizen IM, Hartman P, et al. Mast cell chymase inhibition reduces atherosclerotic plaque progression and improves plaque stability in ApoE-/- mice. Cardiovasc Res. 2011 Jan;89(1):244-52.

111 Sun J, Zhang J, Lindholt JS, Sukhova GK, Liu J, He A, et al. Critical role of mast cell chymase in mouse abdominal aortic aneurysm formation. Circulation. 2009 Sep;120(11): 973-82.

112 Tomimori Y, Manno A, Tanaka T, Futamura-Takahashi J, Muto T, Nagahira K. ASB17061, a novel chymase inhibitor, prevented the development of angiotensin IIinduced abdominal aortic aneurysm in apolipoprotein E-deficient mice. Eur J Pharmacol. 2019 Aug;856:172403.

113 Tsunemi K, Takai S, Nishimoto M, Jin D, Sakaguchi M, Muramatsu M, et al. A specific chymase inhibitor, 2-(5-formylamino6-oxo-2-phenyl-1,6-dihydropyrimidine1-yl)-N-[[3,4-dioxo-1-phenyl-7-(2 pyridyloxy)]-2-heptyl]acetamide (NK3201), suppresses development of abdominal aortic aneurysm in hamsters. J Pharmacol Exp Ther. 2004 Jun;309(3):879-83.

114 Miyaoka Y, Jin D, Tashiro K, Komeda K, Masubuchi S, Hirokawa F, et al. Chymase inhibitor prevents the development and progression of non-alcoholic steatohepatitis in rats fed a high-fat and high-cholesterol diet. J Pharmacol Sci. 2017 Jul;134(3):139-46.

115 Masubuchi S, Takai S, Jin D, Tashiro K, Komeda K, Li ZL, et al. Chymase inhibitor ameliorates hepatic steatosis and fibrosis on established non-alcoholic steatohepatitis in hamsters fed a methionine- and choline-deficient diet. Hepatol Res. 2013 Sep;43(9):970-8.

116 Tashiro K, Takai S, Jin D, Yamamoto H, Komeda K, Hayashi M, et al. Chymase inhibitor prevents the nonalcoholic steatohepatitis in hamsters fed a methionine- and choline-deficient diet. Hepatol Res. 2010 May; 40(5):514-23.

117 Imai Y, Takai S, Jin D, Komeda K, Tashiro $\mathrm{K}$, Li ZL, et al. Chymase inhibition attenuates lipopolysaccharide/ d-galactosamineinduced acute liver failure in hamsters. Pharmacology. 2014;93(1-2):47-56.

118 Komeda K, Takai S, Jin D, Tashiro K, Hayashi M, Tanigawa N, et al. Chymase inhibition attenuates tetrachloride-induced liver fibrosis in hamsters. Hepatol Res. 2010 Aug; 40(8):832-40.

119 Scandiuzzi L, Beghdadi W, Daugas E, Abrink M, Tiwari N, Brochetta C, et al. Mouse mast cell protease- 4 deteriorates renal function by contributing to inflammation and fibrosis in immune complex-mediated glomerulonephritis. J Immunol. 2010 Jul;185(1):624-33.

120 Park S, Bivona BJ, Ford SM Jr, Xu S, Kobori $\mathrm{H}$, de Garavilla L, et al. Direct evidence for intrarenal chymase-dependent angiotensin II formation on the diabetic renal microvasculature. Hypertension. 2013 Feb;61(2): 465-71.

121 Bivona BJ, Takai S, Seth DM, Satou R, Harrison-Bernard LM. Chymase inhibition retards albuminuria in type 2 diabetes. Physiol Rep. 2019 Dec;7(24):e14302.

122 Zhang M, Huang W, Bai J, Nie X, Wang W. Chymase inhibition protects diabetic rats from renal lesions. Mol Med Rep. 2016 Jul; 14(1):121-8.

123 Maeda Y, Inoguchi T, Takei R, Sawada F, Sasaki S, Fujii M, et al. Inhibition of chymase protects against diabetes-induced oxidative stress and renal dysfunction in hamsters. Am J Physiol Renal Physiol. 2010 Dec; 299(6):F1328-38.

124 Takai S, Jin D, Ohzu M, Tanaka K, Miyazaki M. Chymase inhibition provides pancreatic islet protection in hamsters with streptozotocin-induced diabetes. J Pharmacol Sci. 2009 Aug;110(4):459-65.

125 Pons M, Ali L, Beghdadi W, Danelli L, Alison $M$, Madjène LC, et al. Mast cells and MCPT4 chymase promote renal impairment after partial ureteral obstruction. Front Immunol. 2017 May;8:450.
126 Madjene LC, Danelli L, Dahdah A, et al. Mast cell chymase protects against acute ischemic kidney injury by limiting neutrophil hyperactivation and recruitment. Kidney Int. 2020 Mar;97(3):516-27.

127 Tchougounova E, Pejler G. Regulation of extravascular coagulation and fibrinolysis by heparin-dependent mast cell chymase. FASEB J. 2001 Dec;15(14):2763-5.

128 Shubin NJ, Glukhova VA, Clauson M, Truong P, Abrink M, Pejler G, et al. Proteome analysis of mast cell releasates reveals a role for chymase in the regulation of coagulation factor XIIIA levels via proteolytic degradation. J Allergy Clin Immunol. 2017 Jan;139(1):323-34.

129 Watanabe N, Tomimori Y, Saito K, Miura K, Wada A, Tsudzuki M, et al. Chymase inhibitor improves dermatitis in NC/Nga mice. Int Arch Allergy Immunol. 2002 Jul;128(3): 229-34.

$130 \mathrm{He}$ S, Walls AF. Human mast cell chymase induces the accumulation of neutrophils, eosinophils and other inflammatory cells in vivo. $\mathrm{Br}$ J Pharmacol. 1998 Dec;125(7): 1491-500.

131 Terakawa M, Tomimori Y, Goto M, Fukuda Y. Mast cell chymase induces expression of chemokines for neutrophils in eosinophilic EoL-1 cells and mouse peritonitis eosinophils. Eur J Pharmacol. 2006 May;538(1-3): $175-81$.

132 Watanabe N, Miura K, Fukuda Y. Chymase in hibitor ameliorates eosinophilia in mice infected with Nippostrongylus brasiliensis. Int Arch Allergy Immunol. 2002 Jul;128(3):235-9.

133 Terakawa M, Fujieda Y, Tomimori Y, Muto T, Tanaka T, Maruoka H, et al. Oral chymase inhibitor SUN13834 ameliorates skin inflammation as well as pruritus in mouse model for atopic dermatitis. Eur J Pharmacol. 2008 Dec;601(1-3):186-91.

134 Inoue $\mathrm{N}$, Muramatsu $\mathrm{M}$, Jin $\mathrm{D}$, Takai $\mathrm{S}$ Hayashi T, Katayama H, et al. Effects of chymase inhibitor on angiotensin II-induced abdominal aortic aneurysm development in apolipoprotein E-deficient mice. Atherosclerosis. 2009 Jun;204(2):359-64.

135 Liu WX, Wang Y, Sang LX, Zhang S, Wang T, Zhou F, et al. Chymase inhibitor TY51469 in therapy of inflammatory bowel disease. World J Gastroenterol. 2016 Feb;22(5): 1826-33.

136 Groschwitz KR, Ahrens R, Osterfeld H, Gurish MF, Han X, Abrink M, et al. Mast cells regulate homeostatic intestinal epithelial migration and barrier function by a chymase/Mcpt4-dependent mechanism. Proc Natl Acad Sci USA. 2009 Dec;106(52): 22381-6.

137 Scudamore CL, Thornton EM, McMillan L, Newlands GF, Miller HR. Release of the mucosal mast cell granule chymase, rat mast cell protease-II, during anaphylaxis is associated with the rapid development of paracellular permeability to macromolecules in rat jejunum. J Exp Med. 1995 Dec;182(6):1871-81. 
$138 \mathrm{He}$ S, Walls AF. The induction of a prolonged increase in microvascular permeability by human mast cell chymase. Eur J Pharmacol. 1998 Jul;352(1):91-8.

139 Nelissen S, Vangansewinkel T, Geurts N, Geboes L, Lemmens E, Vidal PM, et al. Mast cells protect from post-traumatic spinal cord damage in mice by degrading inflammationassociated cytokines via mouse mast cell protease 4. Neurobiol Dis. 2014 Feb;62:26072.

140 Vangansewinkel T, Lemmens S, Geurts N, Quanten K, Dooley D, Pejler G, et al. Mouse mast cell protease 4 suppresses scar formation after traumatic spinal cord injury. Sci Rep. 2019 Mar;9(1):3715.

141 Hendrix S, Kramer P, Pehl D, Warnke K, Boato F, Nelissen S, et al. Mast cells protect from post-traumatic brain inflammation by the mast cell-specific chymase mouse mast cell protease-4. FASEB J. 2013 Mar;27(3): 920-9.

142 Kakizoe E, Shiota N, Tanabe Y, Shimoura K, Kobayashi Y, Okunishi H. Isoform-selective upregulation of mast cell chymase in the development of skin fibrosis in scleroderma model mice. J Invest Dermatol. 2001 Jan; 116(1):118-23.

143 Shiota N, Kakizoe E, Shimoura K, Tanaka T, Okunishi H. Effect of mast cell chymase inhibitor on the development of scleroderma in tight-skin mice. Br J Pharmacol. 2005 Jun; 145(4):424-31.

144 Watanabe N, Tomimori Y, Terakawa M, Ishiwata K, Wada A, Muto T, et al. Oral administration of chymase inhibitor improves dermatitis in NC/Nga mice. J Invest Dermatol. 2007 Apr;127(4):971-3.

145 Ozeki M, Jin D, Miyaoka Y, Masubuchi S, Hirokawa F, Hayashi M, et al. Comparison of a chymase inhibitor and hyaluronic acid/ carboxymethylcellulose (Seprafilm) in a novel peritoneal adhesion model in rats. PLoS One. 2019 Jan;14(1):e0211391.
146 Soga Y, Takai S, Koyama T, Okamoto Y, Ikeda T, Nishimura K, et al. Attenuation of adhesion formation after cardiac surgery with a chymase inhibitor in a hamster model. J Thorac Cardiovasc Surg. 2004 Jan;127(1): 72-8.

147 Soga Y, Takai S, Koyama T, Okamoto Y, Ikeda T, Nishimura K, et al. Attenuating effects of chymase inhibitor on pericardial adhesion following cardiac surgery. J Card Surg. 2007 Jul-Aug;22(4):343-7.

148 Okamoto Y, Takai S, Miyazaki M. Significance of chymase inhibition for prevention of adhesion formation. Eur J Pharmacol. 2004 Jan;484(2-3):357-9.

149 Okamoto Y, Takai S, Miyazaki M. Oral administration of a novel chymase inhibitor, NK3201, prevents peritoneal adhesion formation in hamsters. Jpn J Pharmacol. 2002 Sep;90(1):94-6.

150 King SJ, Miller HR. Anaphylactic release of mucosal mast cell protease and its relationship to gut permeability in Nippostrongylus-primed rats. Immunology. $1984 \mathrm{Apr}$; 51(4):653-60.

151 Lind T, Gustafson AM, Calounova G, Hu L, Rasmusson A, Jonsson KB, et al. Increased Bone Mass in Female Mice Lacking Mast Cell Chymase. PLoS One. 2016 Dec; 11(12): 0167964.

152 Masaki H, Mizuno Y, Tatui A, Murakami A, Koide Y, Satoh S, et al. Structure-activity relationship of benzo[b]thiophene-2-sulfonamide derivatives as novel human chymase inhibitors. Bioorg Med Chem Lett. 2003 Nov;13(22):4085-8.

153 Takai S, Jin D, Nishimoto M, Yuda A, Sakaguchi $\mathrm{M}$, Kamoshita $\mathrm{K}$, et al. Oral administration of a specific chymase inhibitor, NK3201, inhibits vascular proliferation in grafted vein. Life Sci. 2001 Aug;69(15): 1725-32.

154 Fukami H, Imajo S, Ito A, Kakutani S, Shibata H, Sumida M, et al. Substituted 3-phenylsulfonylquinazoline-2,4-dione derivatives as novel nonpeptide inhibitors of human heart chymase. Drug Des Discov. 2000; 17(1):69-84.
155 Tomimori Y, Tsuruoka N, Fukami H, Saito K, Horikawa C, Saito M, et al. Role of mast cell chymase in allergen-induced biphasic skin reaction. Biochem Pharmacol. 2002 Oct;64(7):1187-93.

156 Takai S, Jin D, Sakaguchi M, Kirimura K, Miyazaki M. An orally active chymase inhibitor, $\mathrm{BCEAB}$, suppresses heart chymase activity in the hamster. Jpn J Pharmacol. 2001 May;86(1):124-6.

157 Shimatani T, Hosotani N, Ohnishi M, Kumagai K, Saji I. SPF-32629 A and B, novel human chymase inhibitors produced by Penicillium sp. J Antibiot (Tokyo). 2006 Jan; 59(1):29-34.

158 Imada T, Komorita N, Kobayashi F, Naito K, Yoshikawa T, Miyazaki M, et al. Therapeutic potential of a specific chymase inhibitor in atopic dermatitis. Jpn J Pharmacol. 2002 Nov;90(3):214-7.

159 Tinel H, Zubov D, Zimmermann K, Tersteegen $\mathrm{A}$, Boerngen $\mathrm{K}$, Joerissen $\mathrm{H}$, et al. Abstract 13624: a novel chymase inhibitor BAY 1142524 reduces fibrosis and improves cardiac function after myocardial infarction in hamster. Circulation. 2017;136:A13624.

160 Bastos M, Maeji NJ, Abeles RH. Inhibitors of human heart chymase based on a peptide library. Proc Natl Acad Sci USA. 1995 Jul; 92(15):6738-42.

161 Raymond WW, Ruggles SW, Craik CS, Caughey GH. Albumin is a substrate of human chymase. Prediction by combinatorial peptide screening and development of a selective inhibitor based on the albumin cleavage site. J Biol Chem. 2003 Sep;278(36): 34517-24.

162 Oleksyszyn J, Powers JC. Irreversible inhibition of serine proteases by peptide derivatives of (alpha-aminoalkyl)phosphonate diphenyl esters. Biochemistry. 1991 Jan;30(2): 485-93.

163 Ngo Nyekel F, Pacreau E, Benadda S, Msallam R, Åbrink M, Pejler G, et al. Mast cell degranulation exacerbates skin rejection by enhancing neutrophil recruitment. Front Immunol. 2018 Nov;9:2690. 